\title{
Quantitative Analysis of Weissella cibaria against Periodontopathic Bacteria by Real-time PCR
}

\author{
Mi-Sun Kang, ${ }^{1}$ Hoi-Soon Lim², Seon-Mi Kim², You-Jin Lim³, \\ Hyun-Chul Lee ${ }^{1}$ and Jong-Suk $\mathrm{Oh}^{1 *}$ \\ ${ }^{1}$ Department of Microbiology, School of Medicine, ${ }^{2}$ Dental Science Research Institute, Chonnam National University, \\ Gwangju, Korea, ${ }^{3}$ Department of Nursing, Chunnam Techno Colleage, Gokseong, Jeonnam, Korea
}

The objective of this study was to analyze quantitatively whether Weissella cibaria could affect the proliferation of five periodontopathic bacteria, Porphyromonas gingivalis, Tannerella forsythia, Treponema denticola, Aggregatibacter actinomycetemcomitans, and Fusobacterium nucleatum, after incubation for $8 \sim 48 \mathrm{~h}$. In addition, by using real-time PCR with a dual-labeled probe, each growth of bacteria was examined under different growth media conditions. The proliferation of periodontopathic bacteria was significantly inhibited by $W$. cibaria after incubation for $24 \sim 48 \mathrm{~h}(p<$ $0.05)$, whereas the growth of $W$. cibaria was not affected by these pathogenic bacteria. The growth of $P$. gingivalis, $T$. forsythia and $T$. denticola significantly increased in each growth media after incubation for $24 \mathrm{~h}(p<0.05)$, as compared to the culture in mixed growth media. However, no differences in the growth of five periodontopathic bacteria were observed between each growth media and mixed media after incubation for $48 \mathrm{~h}$. The growth and $\mathrm{pH}$ of $W$. cibaria culture significantly were changed in MRS after incubation for $24 \sim 48 \mathrm{~h}(p<0.05)$, as compared to the bacterial culture in mixed growth media. The $\mathrm{pH}$ of $P$. gingivalis and $F$. nucleatum culture significantly was changed in both growth media and mixed media after incubation for $24 \sim 48 \mathrm{~h}(p<0.05)$. Our data indicate that $W$. cibaria significantly inhibits the proliferation of five periodontopathic bacteria and each growth of bacteria is quantitatively analyzed under various media conditions by real-time PCR.

Key Words: Periodontopathic bacteria, Proliferation, Real-time PCR, Weissella cibaria

\section{서 론 \\ 치주질환은 일명 풍치라 부르는 질환으로 치과질환에 서 치아우식증과 함께 구강의 2대 질환 중 하나다. 치주 질환은 성인에서 치아상실을 초래하는 가장 중요한 원 인 질환으로서, 구강 내에 존재하는 치주질환 원인균 및}

Received: September 8, 2009/ Revised: September 29, 2009 Accepted: October 7, 2009

*Corresponding author: Jong-Suk Oh, M.D., Ph.D. Department of Microbiology, School of Medicine, Chonnam National University, 5 Hak-Dong, Dong-Gu, Gwangju 501-746, Korea.

Phone: +82-62-220-4134, Fax: +82-62-228-7294 e-mail: joh@chonnam.ac.kr

** This study was supported by a grant (CRI09037-1) of the Chonnam National University Hospital Research Institute of Clinical Medicine.
이 세균들이 생성하는 독소들에 의해서 치주조직이 파괴 되는 염증성 질환이다 (1 3). 치주질환의 진행 억제 및 예방을 위해서는 치태를 형성하는 세균을 제거하는 것이 필수적인데, 그동안 다양한 항생제를 비롯한 구강세정제 등을 사용하여 구강의 치태형성을 억제하기 위한 많은 노력들이 있어 왔다. Poulet 등 (4)은 metronidazole 등의 항생제가 Prevotella intermedia, Porphyromonas gingivalis, Fusobacterium에 대해 효과적이었음을 보고한 바 있으며, Roldan 등 (5)은 cholorhexidine 및 zinc chloride가 함유된 구강세정제가 구강세균에 효과가 있음을 보고한 바 있다. 그러나 항생제는 내성균의 출현 및 균교대증과 같은 부 작용이 있으며, 구강세정제의 경우 일시적인 효과는 있 을 수 있으나 세정제 내의 강력한 화학제재 때문에 병 원균과 함께 구강내 상주균도 제거될 수 있으므로 장기 
간 사용하면 오히려 부작용을 일으킬 수 있다. 따라서, 합성 화학제재의 대체제로서 천연물질 $(6,7)$ 이나 유산균 과 같은 프로바이오틱 $(8,9)$ 의 활용이 대두되고 있으나, 아직까지 다양한 치주질환 원인균에 대한 유산균의 억제 효과를 본 연구는 찾아보기 어렵다.

구강내 많은 세균들 중에서 Aggregatibacter actinomycetemcomitans (이전에는 Actinobacillus actinomycetemcomitans 로 명명됨)는 국소적 공격형 치주염과 관련이 있으며 (10), red complex로 분류되는 P. gingivalis, Tannerella forsythia (이전에는 Bacteroides forsythus로 명명됨), Treponema denticola는 성인의 치주질환에 중요한 역할을 하는 원 인균이다. 또한, orange complex의 하나인 Fusobacterium nucleatum 등도 치주질환에 관여하는 세균으로 알려져 있다 $(11,12)$. 이들 치주질환 원인균은 그람음성 혐기성 세균으로서 실험실에서 배양하기가 매우 까다롭고 전통 적인 세균배양 방법으로는 유산균이 이들 세균의 성장에 미치는 영향을 정량적으로 측정하기가 어렵다. 실시간 중 합효소연쇄반응 (real-time polymerase chain reaction, realtime PCR)은 세균 특이성이 있는 primer와 probe를 이용 하여 지수적 증식 단계를 조사함으로써 세균의 정량적 분석이 가능하며, 최근에는 이를 통해 치주질환 원인균에 대한 연구가 많이 이루어지고 있다 (13 16). 이들 치주 질환 원인균의 양을 비교 조사하는 것은 치주질환에 있 어서 세균의 역할을 이해하는데 중요하다고 할 수 있다.

Weissella는 최근 DNA 기술의 발달에 따라 Lactobacillus 속에서 새로 분리된 유산균으로서 (17), Weissella cibaria 는 그람양성, 비포자 형성, 비운동성, hetero 유산발효, 카 탈라아제 음성 막대균이고, 자당으로부터 덱스트란을 생 성할 수 있으며, 발효식품과 사람과 동물에서 정상적으로 분리되는 세균이다 (18). 최근에 본 연구실에서는 구강에 서 분리한 W. cibaria가 강산을 만들지 않고 수용성 글루 캔과 과산화수소를 분비하여 충치 및 구취를 억제하여 구강에 이로운 역할을 한다고 보고하였다 $(19,20)$. 따라 서, 본 연구의 목적은 W. cibaria가 치주질환 원인균의 생육에 미치는 영향을 real-time PCR을 통해서 정량적 으로 측정하고자 하였다. 또한, 치주질환 원인균 및 $W$. cibaria의 성장력을 단독 성장배지와 혼합배지에서 정량 적으로 비교하고자 하였다.

\section{재료 및 방법}

\section{균주 및 배양}

실험균주로는 구강이 건강한 4 5세 유아의 타액에서 분리한 W. cibaria CMS2 균주와 A. actinomycetemcomitans ATCC 33384, P. gingivalis ATCC 33277, T. forsythia ATCC 43037, T. denticola ATCC 35405, F. nucleatum ATCC 10953 을 이용하였다. W. cibaria는 De Man, Rogosa, Sharpe broth (MRS, Difco, Detroit, MI, USA)에 접종하여 $37^{\circ} \mathrm{C}$ 호기조 건에서 16시간 배양하였다. A. actinomycetemcomitans는 1 $\mathrm{mg} / \mathrm{ml}$ yeast extract (Difco)와 10\% horse serum (Hyclone, Logan, UT, USA)이 첨가된 $3 \%$ tryptic soy broth (Difco)에, P. gingivalis는 yeast extract $(1 \mathrm{mg} / \mathrm{ml}), 5 \mu \mathrm{g} / \mathrm{ml}$ haemin (Sigma, St Louis, MO, USA), $1 \mu \mathrm{g} / \mathrm{ml}$ menadione (Sigma)이 첨가된 Brucella broth (Difco)에, F. nucleatum은 yeast extract (1 $\mathrm{mg} / \mathrm{ml})$, haemin $(10 \mu \mathrm{g} / \mathrm{ml})$, menadione $(5 \mu \mathrm{g} / \mathrm{ml})$ 이 첨가된 Brucella broth에, T. forsythia는 yeast extract $(0.5 \mathrm{mg} / \mathrm{ml})$, haemin $(5 \mu \mathrm{g} / \mathrm{ml})$, menadione $(0.5 \mu \mathrm{g} / \mathrm{ml})$, N-acetylmuramic acid $(10 \mu \mathrm{g} / \mathrm{ml}), 10 \%$ fetal bovine serum (Hyclone)이 첨가된 Brucella broth에 (21), T. denticola는 TYGVS medium [tryptone $(10 \mathrm{mg} / \mathrm{ml})$, brain heart infusion broth $(5 \mathrm{mg} / \mathrm{ml})$, yeast extract $(10 \mathrm{mg} / \mathrm{ml})$, gelatin $(10 \mathrm{mg} / \mathrm{ml}),\left(\mathrm{NH}_{4}\right)_{2} \mathrm{SO}_{4}(0.5$ $\mathrm{mg} / \mathrm{ml}), \mathrm{MgSO}_{4}(0.1 \mathrm{mg} / \mathrm{ml}), \mathrm{K}_{2} \mathrm{HPO}_{4}(1.13 \mathrm{mg} / \mathrm{ml}), \mathrm{KH}_{2} \mathrm{PO}_{4}$ $(0.9 \mathrm{mg} / \mathrm{ml}), \mathrm{NaCl}(1 \mathrm{mg} / \mathrm{ml})$, glucose $(1 \mathrm{mg} / \mathrm{ml})$, cysteine hydrochloride $(1 \mathrm{mg} / \mathrm{ml})$, thiamine pyrophosphate $(12.5 \mu \mathrm{g} / \mathrm{ml})$, sodium pyruvate $(0.25 \mathrm{mg} / \mathrm{ml}), 0.027 \%$ acetic acid, $0.01 \%$ propionic acid, $0.0064 \%$ n-butyric acid, $0.0016 \%$ n-valeric acid, $0.0016 \%$ isobutyric acid, $0.0016 \%$ isovaleric acid, $0.0016 \%$ DL-methylbutyric acid, $10 \%$ heat-inactivated rabbit serum] (22) 에 각각 접종하여 $37^{\circ} \mathrm{C}$ 혐기조건 $\left(85 \% \mathrm{~N}_{2}, 10 \% \mathrm{H}_{2}, 5 \%\right.$ $\mathrm{CO}_{2}$ )에서 48 시간 배양하였다. 각각의 균은 실험에 이용 하기 전에 본 배지에서 2 회 계대배양한 후 실험에 이용 하였다.

\section{치주질환 원인균의 성장에 대한 W. cibaria의 영향}

Real-time PCR을 이용하여 치주질환 원인균에 대한 $W$. cibaria의 영향을 보기 위하여 상기의 5 종류 혐기성 세균 의 성장배지와 W. cibaria의 성장배지인 MRS를 $1: 1$ 로 각 각 혼합한 후 W. cibaria의 산생성에 의한 억제효과를 배제하고자 0.1 M MES (2-morpholinoethanesulfonic acid) 
buffer를 첨가하여 $\mathrm{pH} 7.2$ 를 맞춘 $12 \mathrm{ml}$ 의 배지에 각각의 혐기성 세균 $\left(2.5 \times 10^{7} / \mathrm{ml}\right)$ 과 W. cibaria $\left(2.5 \times 10^{6} / \mathrm{ml}\right)$ 를 단독 또는 병합으로 접종하였다. $0,8,24,48$ 시간 혐기배양 후 배양액을 $1 \mathrm{ml}$ 씩 취하여 $\mathrm{DNA}$ 를 추출한 후 $4{ }^{\circ} \mathrm{C}$ 에 보 관하면서 real-time PCR을 실시하였다.

\section{치주질환 원인균의 성장에 대한 배지의 영향}

치주질환 원인균이 상기의 W. cibaria 성장배지가 혼합 된 배지에서 배양했을 때와 단독 성장배지에서 배양했을 때 성장에 어느 정도 차이가 있는지를 알아 보기 위하여 $0.1 \mathrm{M} \mathrm{MES}$ 가 첨가된 MRS 배지와 혐기성 세균의 성장배 지를 $1: 1$ 로 혼합한 $12 \mathrm{ml}$ 의 배지와 혼합하지 않은 $12 \mathrm{ml}$ 의 단독배지에서 각각 치주질환 원인균 $\left(2.5 \times 10^{7} / \mathrm{ml}\right)$ 을 접종하였다. $0,8,24,48$ 시간 혐기배양 후 배양액을 $1 \mathrm{ml}$ 씩 취하여 $\mathrm{DNA}$ 를 추출한 후 $4^{\circ} \mathrm{C}$ 에 보관하면서 real-time $\mathrm{PCR}$ 을 실시하였다. 또한, 성장에 따른 $\mathrm{pH}$ 변화를 측정 하기 위하여 $\mathrm{pH}$ meter (Corning Inc., Corning, NY, USA)를 이용하여 배양시간에 따른 $\mathrm{pH}$ 변화를 측정하였다.

\section{W. cibaria의 성장에 대한 배지의 영향}

W. cibaria가 혐기성 세균의 성장배지를 혼합한 배지와 MRS 단독배지에서 각각 배양하였을 때 성장의 정도에 차이가 있는지를 알아 보기 위하여 0.1 M MES가 첨가된 $12 \mathrm{ml}$ 의 $\mathrm{MRS}$ 배지와 각 혐기성 세균의 성장배지를 $1: 1$ 로 혼합한 $12 \mathrm{ml}$ 의 배지에서 각각 W. cibaria $\left(2.5 \times 10^{6}\right.$ / $\mathrm{ml}$ )를 접종하였다. $0,8,24,48$ 시간 호기배양 후 배양액을 $1 \mathrm{ml}$ 씩 취하여 $\mathrm{DNA}$ 를 추출한 후 $4^{\circ} \mathrm{C}$ 에 보관하면서 realtime PCR을 실시하였으며, 배양시간에 따른 $\mathrm{pH}$ 변화도 함께 측정하였다.

\section{Chromosomal DNA 추출}

배양액을 $1 \mathrm{ml}$ 씩 취하여 원심분리 $(12,000 \mathrm{rpm}, 2 \mathrm{~min}$, $4{ }^{\circ} \mathrm{C}$ )한 후 phosphate-buffered saline (PBS)으로 2회 세척한 후 다시 PBS $0.5 \mathrm{ml}$ 로 부유한 다음 cell lysis buffer $(20 \mathrm{mM}$ Tris- $\mathrm{HCl}, 1 \%$ Triton X-100, $2 \mathrm{mM}$ EDTA, pH 8.0) 0.5 ml로 혼 합한 후 $100^{\circ} \mathrm{C}$ 에서 10 분간 끓여서 chromosomal DNA를
A
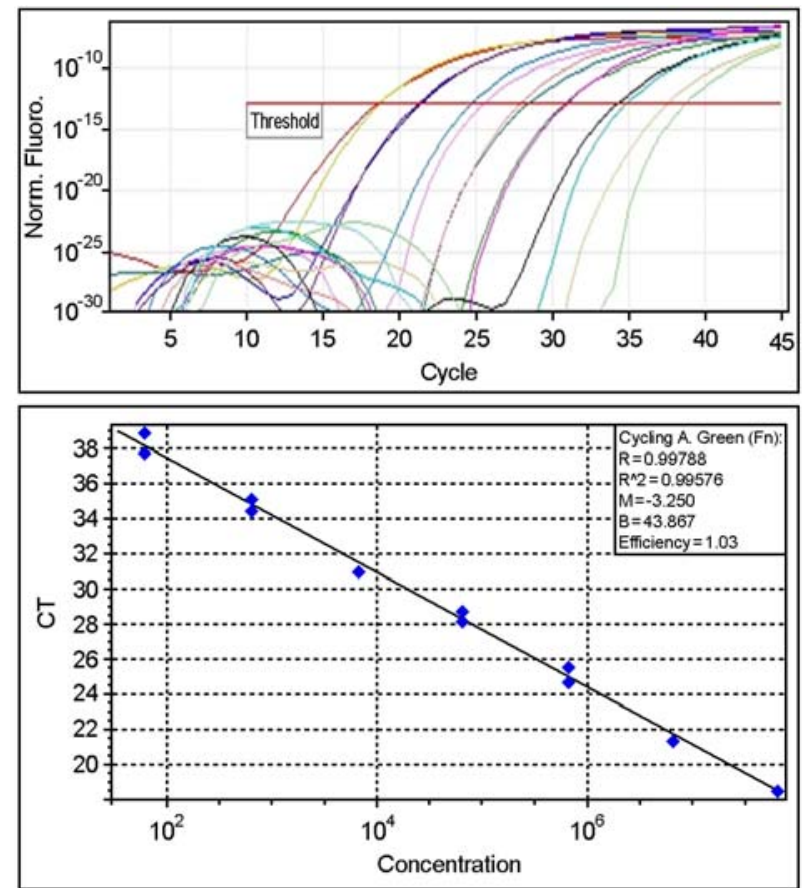

B
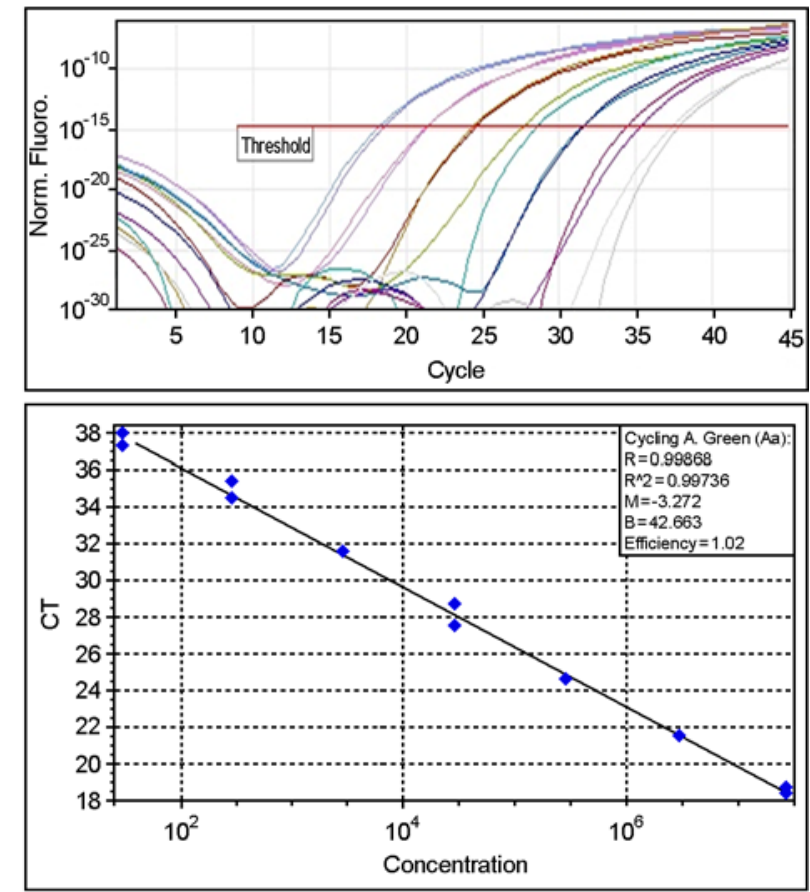

Figure 1. Amplification of genomic DNA from lysed cells. Serial dilutions of genomic DNA from F. nucleatum (A) or A. actinomycetemcomitans (B) were used as templates for real-time PCR. The threshold fluorescence, or the level at which the threshold cycle was determined, is shown. The standard curves were generated from the amplification plots in the insets (correlation coefficients, 0.996 for F. nucleatum and 0.997 for A. actinomycetemcomitans). CT is the cycle number at which the threshold fluorescence is reached. The linearity with $\mathrm{R}$ value is observed from $10^{2}$ to $10^{8}$ bacterial cells. 
Table 1. Species-specific primers and probes used for real-time PCR

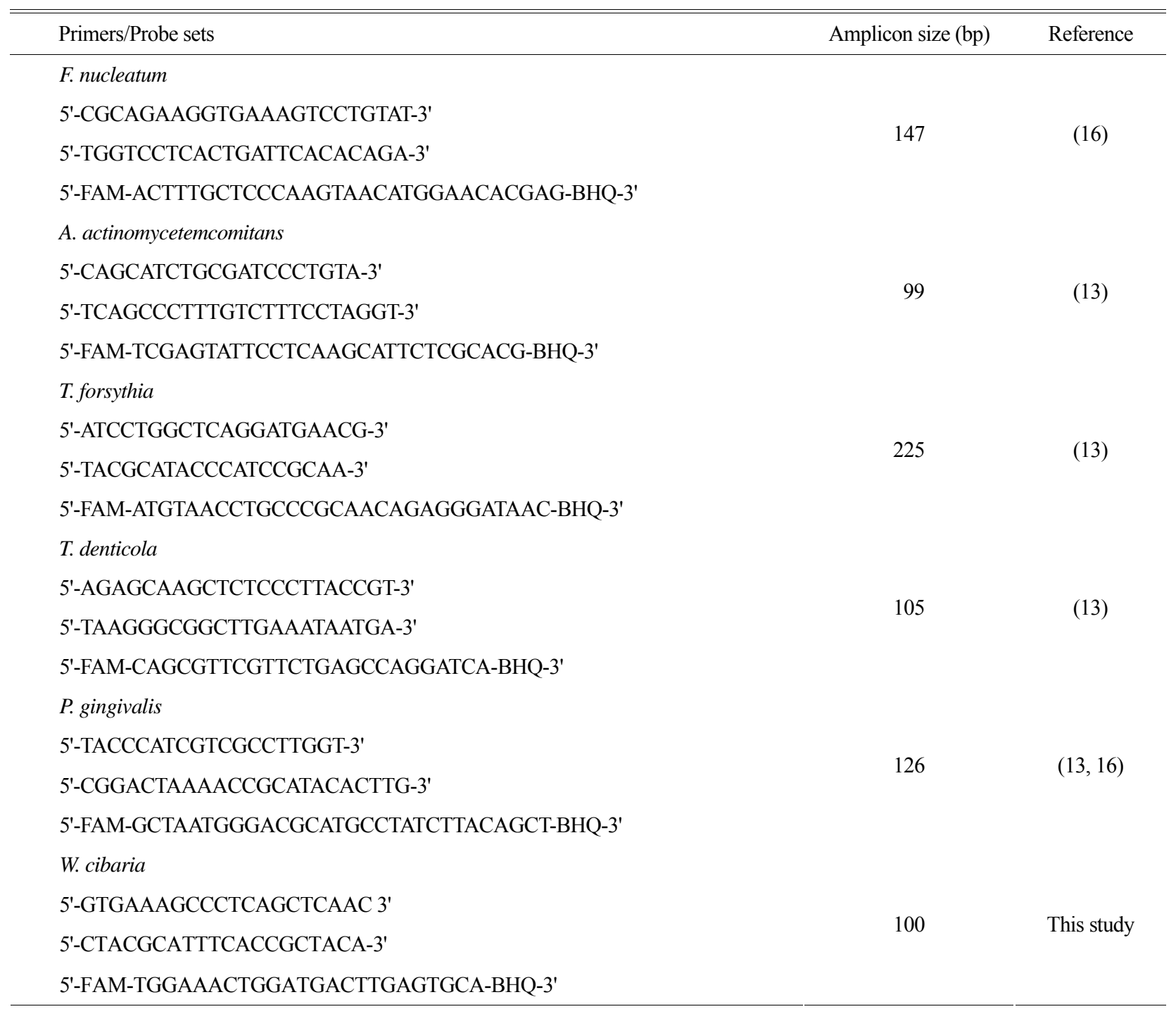

추출하였다. PCR 조건의 표준화를 위해 각각의 성장배지 에 배양한 5종류의 혐기성 세균은 Petroff-Hausser bacterial counting chamber (Hausser and Son, Philadelphia, PA, USA) 를 이용하여 세균수를 측정하였으며, W. cibaria는 MRS agar를 이용하여 생균수를 측정하였다. 상기의 방법으로 DNA를 추출한 후 DNA를 $10^{2} \sim 10^{8}$ 까지 10 배씩 연속적 으로 희석하여 real-time PCR 정량에 필요한 표준곡선을 작성하였다 (Fig. 1). Cycle threshold (CT)는 알려진 숫자의 DNA 농도의 대수기에서 시작하며, 세균수에 대한 표준 곡선에 의해서 시료당 세균수가 측정되도록 하였다.

\section{Real-time PCR}

Real-time PCR은 DNA template $3 \mu \mathrm{l}, 2 \times$ QuantiTect Probe PCR Master Mix (QIAGEN, Strasse, Hilden, Germany) $12.5 \mu \mathrm{l}$, 양방향의 각 primer (10 pmol), dual-labeled probe $(10 \mathrm{pmol})$, 그리고 3 차 멸균수를 첨가하여 최종 용량을 25 $\mu 1$ 로 하였다. Oligonucleotide probes (Operon Biotechnologies, Nattermannallee, Cologne, Germany)는 5' 말단에는 6carboxyfluorescein (FAM), 3' 말단에는 Black Hole Quencher (BHQ-1)가 표지된 것을 이용하였으며, 이들 특정 primer 와 probe set는 Table 1에 나타내었다 $(13,16)$. Rotor Gene 3000 system (Corbett Research, Mortlake, Sydney, Australia)을 
이용하여 중합효소연쇄반응을 시행하였으며, 반응조건은 $95^{\circ} \mathrm{C}$ 에서 15 분간 최초 변성 후 50 주기 동안 $95^{\circ} \mathrm{C}$ 에서 15 초, $58^{\circ} \mathrm{C}$ 에서 1 분간 시행하였다. 실험결과는 Rotor-Gene
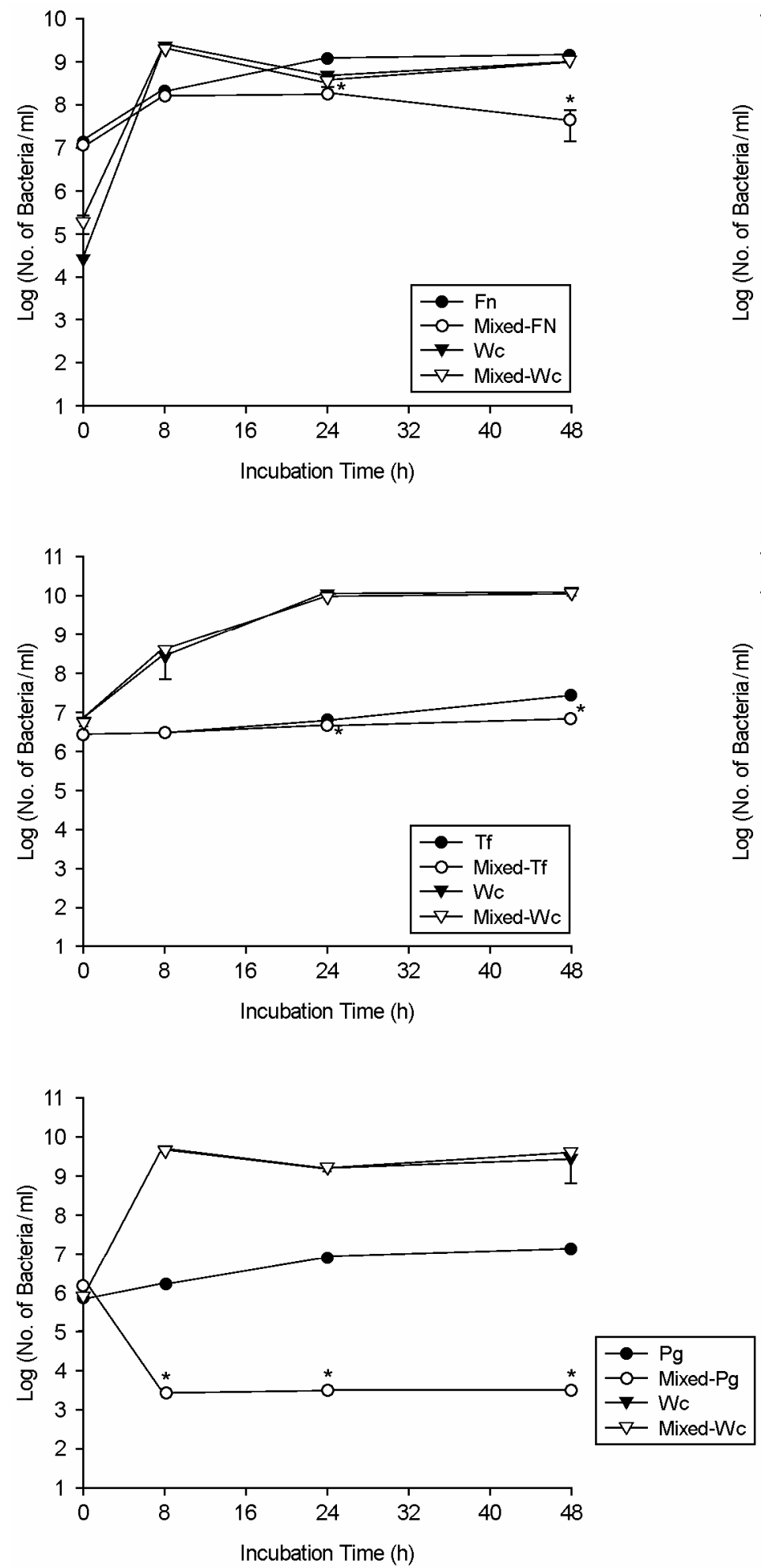

analysis software version 6.0 (Corbett Research)에 의하여 측 정 및 분석하였다.
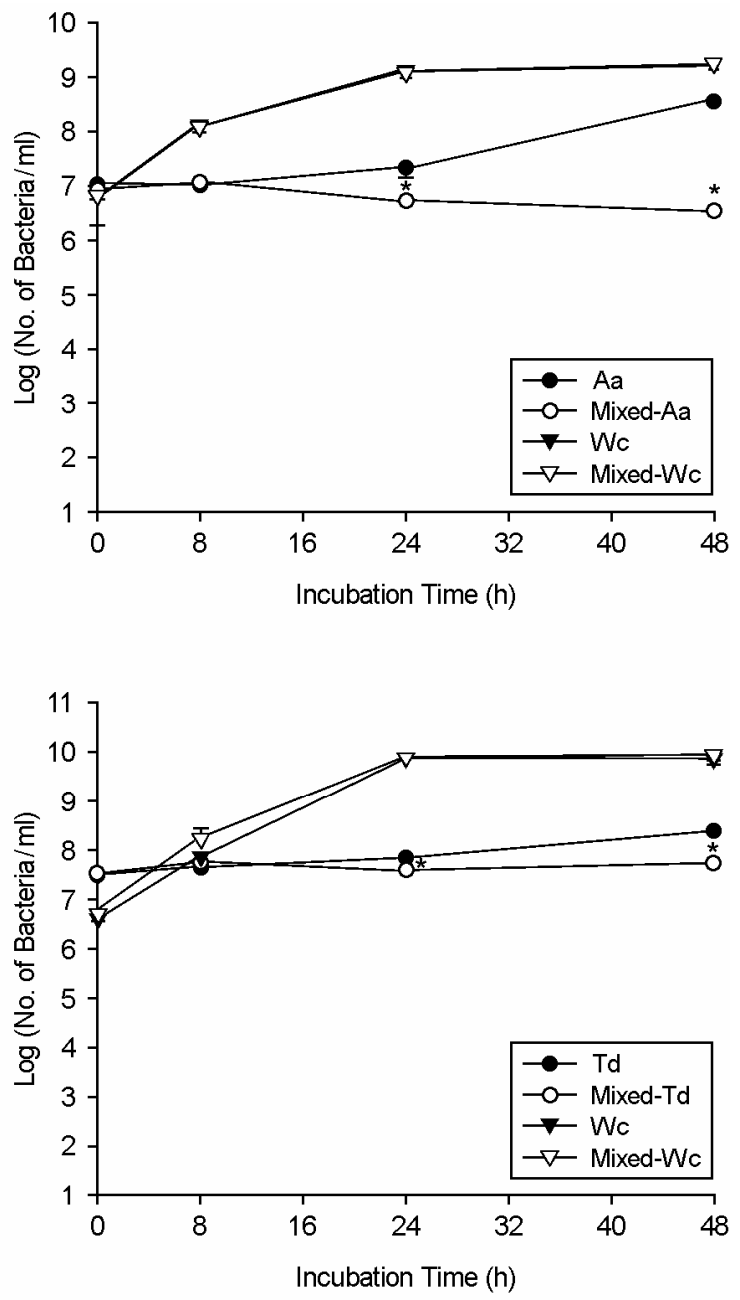

Figure 2. Quantitative comparison of bacterial cell numbers of $W$. cibaria and periodontopathic bacteria in the mixed cultures by real-time PCR. Fn, F. nucleatum; Aa, A. actinomycetemcomitans; Tf, T. forsythia; Td, T. denticola; Pg, P. gingivalis; Wc, W. cibaria. ${ }^{*} p<0.05$ for coculture versus monoculture. Values are means \pm standard deviations of three independent experiments. 


\section{통계 분석}

통계적 처리는 SPSS 통계분석 프로그램 (SPSS version 12.0)을 사용하였으며, Mann-Whitney U-test로 분석하였다.

\section{결 과}

\section{치주질환 원인균 성장에 대한 W. cibaria의 영향}

치주질환 원인균의 성장에 대한 W. cibaria의 영향을 보기 위하여 5 종의 치주질환 원인균과 W. cibaria의 혼 합배양 후 배양시간에 따른 세균수의 변화를 real-time $\mathrm{PCR}$ 을 이용하여 측정한 결과 (Fig. 2), W. cibaria와 병합 으로 배양했을 때 F. nucleatum, A. actinomycetemcomitans, T. forsythia, T. denticola의 생육이 24시간부터 48시간까 지 유의하게 감소하였다 $(p<0.05)$. F. nucleatum와 A. actinomycetemcomitans의 경우 48시간 단독배양 후 각각 배양액 $1 \mathrm{ml}$ 당 균수가 $1.3 \times 10^{9} \pm 1.3 \times 10^{8}, 3.2 \times 10^{8}$ $\pm 7.2 \times 10^{7}$ 이었으며, W. cibaria와 병합으로 배양시에는 배양액 $1 \mathrm{ml}$ 당 균수가 $4.4 \times 10^{7} \pm 3.1 \times 10^{7}, 3.4 \times 10^{6}$ $\pm 5.0 \times 10^{5}$ 로서 각각 약 30 배와 100 배씩 감소하였다. $T$. forsythia, T. denticola의 경우 48시간 배양 후에는 단독배 양시 배양액 $1 \mathrm{ml}$ 당 균수가 각각 $2.7 \times 10^{7} \pm 1.7 \times 10^{6}$, $2.5 \times 10^{8} \pm 6.0 \times 10^{7}$ 이었으며, W. cibaria와 병합으로 배양시에는 각각 배양액 $1 \mathrm{ml}$ 당 균수가 $7.0 \times 10^{6} \pm 4.0$ $\times 10^{5}, 5.5 \times 10^{7} \pm 8.1 \times 10^{6}$ 로서 약 4 배와 5 배씩 감소 하였다. 또한, P. gingivalis의 생육은 W. cibaria와 병합으로 배양시 8시간부터 유의하게 감소하기 시작하여, 48 시간 에는 단독배양한 균수가 $1 \mathrm{ml}$ 당 $1.2 \times 10^{7} \pm 1.3 \times 10^{6}$ 인데 비해 W. cibaria와 병합으로 배양시 $1 \mathrm{ml}$ 당 균수가 $2.8 \times 10^{3} \pm 2.6 \times 10^{2}$ 로 약 $4.5 \times 10^{3}$ 배 감소하였다 $(p$ $<0.05)$. 따라서, P. gingivalis에 대한 억제력이 가장 우수 하였다. 반면, W. cibaria는 5 종의 치주질환 원인균과 혼합 배양하였을 때 세균수에 대한 변화가 거의 없었다.

\section{치주질환 원인균의 성장에 대한 배지의 영향}

치주질환 원인균이 상기의 W. cibaria 성장배지가 혼합 된 배지에서 배양했을 때와 단독 성장배지에서 배양했 을 때 성장의 정도에 차이가 있는지를 알아 본 결과 (Fig. 3 ), 5 종의 치주질환 원인균 모두 단독 성장배지에서 배양 하였을 때 생육이 더 우수하였다. 특히, red complex로 분 류되는 P. gingivalis, T. forsythia, T. denticola는 모두 혼합배
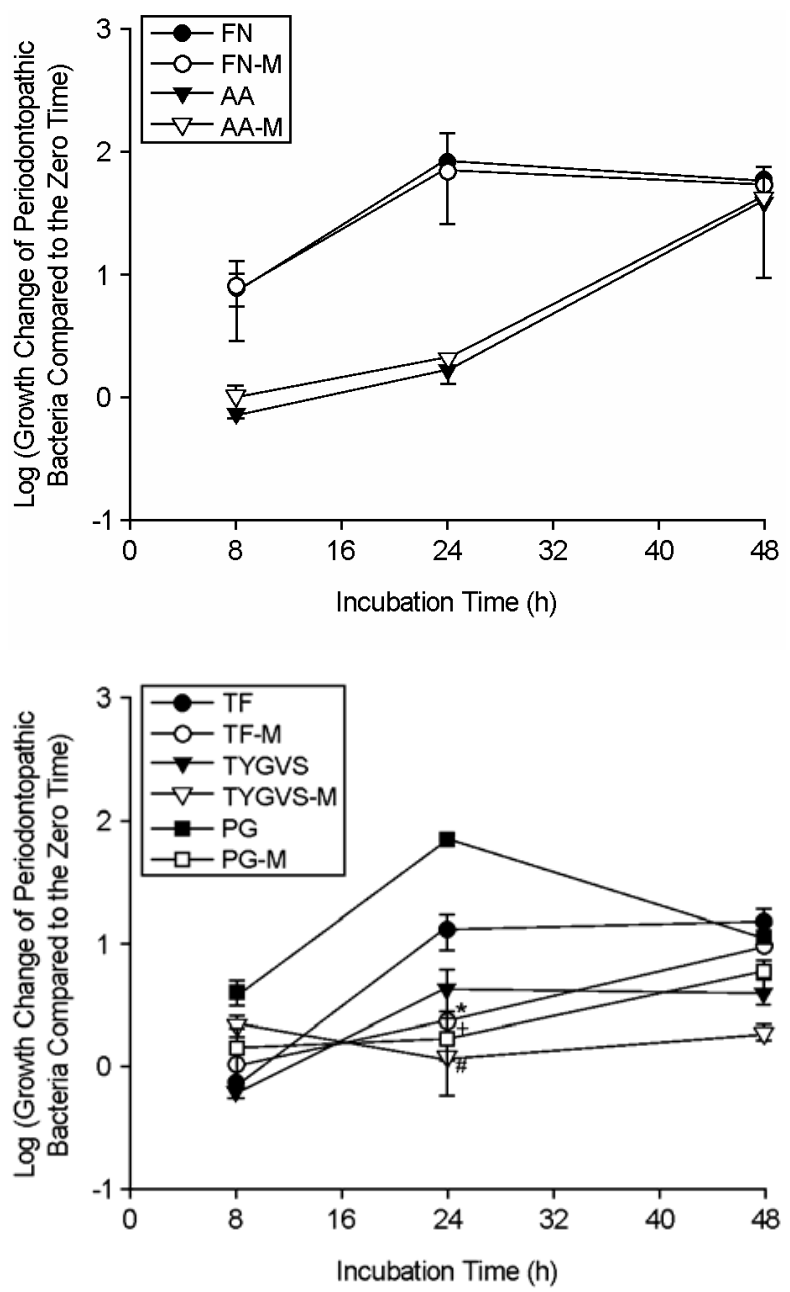

Figure 3. Comparison of bacterial cell numbers of periodontopathic bacteria over time under different growth media conditions by real-time PCR. The growth change of periodontopathic bacteria compared to the zero time $(0 \mathrm{~h})$ was shown as log scale. $F$. nucleatum was grown in FN (F. nucleatum growth medium) or FN-M (a mixture of equal volume of FN and MRS). A. actinomycetemcomitans was grown in AA (A. actinomycetemcomitans growth medium) or AA-M (a mixture of equal volume of AA and MRS). T. forsythia was grown in TF (T. forsythia growth medium) or TF-M (a mixture of equal volume of TF and MRS). T. denticola was grown in TYGVS (T. denticola growth medium) or TYGVS-M (a mixture of equal volume of TYGVS and MRS). $P$. gingivalis was grown in PG (P. gingivalis growth medium) or PG-M (a mixture of equal volume of $\mathrm{PG}$ and MRS). ${ }^{*} p<0.05$, $T$. forsythia culture in TF-M versus T. forsythia culture in TF; \#p < 0.05, T. denticola culture in TYGVS-M versus $T$. denticola culture in TYGVS; $+p<0.05, P$. gingivalis culture in PG-M versus $P$. gingivalis culture in PG. Values are means \pm standard deviations of three independent experiments.

지보다는 단독 성장배지에서 24시간 배양하였을 때 생육 이 약 5 48배 더 좋았으나 $(p<0.05), 48$ 시간 후에는 큰 차이가 없었으며, F. nucleatum과 A. actinomycetemcomitans 
Table 2. The $\mathrm{pH}$ changes of periodontopathic bacterial culture over time under different growth media conditions

\begin{tabular}{|c|c|c|c|c|}
\hline Incubation time $(\mathrm{h})$ & 0 & 8 & 24 & 48 \\
\hline \multicolumn{5}{|l|}{ F. nucleatum } \\
\hline $\mathrm{FN}$ & $6.91 \pm 0.01$ & $6.93 \pm 0.03$ & $6.82 \pm 0.02^{*}$ & $6.79 \pm 0.07^{*}$ \\
\hline FN-M & $6.81 \pm 0.01$ & $6.80 \pm 0.01$ & $6.74 \pm 0.04^{*}$ & $6.56 \pm 0.06^{*}$ \\
\hline \multicolumn{5}{|c|}{ A. actinomycetemcomitans } \\
\hline AA & $6.91 \pm 0.01$ & $6.86 \pm 0.04$ & $6.91 \pm 0.05$ & $6.47 \pm 0.07^{*}$ \\
\hline AA-M & $6.79 \pm 0.09$ & $6.78 \pm 0.03$ & $6.74 \pm 0.04$ & $6.07 \pm 0.07^{*}$ \\
\hline \multicolumn{5}{|l|}{ T. forsythia } \\
\hline $\mathrm{TF}$ & $6.82 \pm 0.06$ & $6.80 \pm 0.10$ & $6.83 \pm 0.13$ & $6.84 \pm 0.04$ \\
\hline TF-M & $6.74 \pm 0.04$ & $6.76 \pm 0.06$ & $6.80 \pm 0.10$ & $6.78 \pm 0.08$ \\
\hline \multicolumn{5}{|l|}{ T. denticola } \\
\hline TYGVS & $7.01 \pm 0.19$ & $7.01 \pm 0.19$ & $7.08 \pm 0.08$ & $7.08 \pm 0.08$ \\
\hline TYGVS-M & $6.86 \pm 0.02$ & $6.86 \pm 0.07$ & $6.84 \pm 0.04$ & $6.84 \pm 0.04$ \\
\hline \multicolumn{5}{|l|}{ P. gingivalis } \\
\hline PG & $6.93 \pm 0.03$ & $6.97 \pm 0.06$ & $7.14 \pm 0.13^{*}$ & $7.12 \pm 0.13^{*}$ \\
\hline PG-M & $6.78 \pm 0.03$ & $6.81 \pm 0.01$ & $6.82 \pm 0.02^{*}$ & $6.82 \pm 0.02^{*}$ \\
\hline
\end{tabular}

FN, F. nucleatum growth medium; FN-M, a mixture of equal volume of FN and MRS; AA, A. actinomycetemcomitans growth medium; AA-M, a mixture of equal volume of AA and MRS; TF, T. forsythia growth medium; TF-M, a mixture of equal volume of TF and MRS; TYGVS, T. denticola growth medium; TYGVS-M, a mixture of equal volume of TYGVS and MRS; PG, P. gingivalis growth medium; PG-M, a mixture of equal volume of $\mathrm{PG}$ and MRS. ${ }^{*} p<0.05, \mathrm{pH}$ at over time versus $\mathrm{pH}$ at zero time. Values are means \pm standard deviations of three independent experiments

는 48시간 동안 계속하여 배지에 따른 성장의 차이를 보이지 않았다. 성장에 따른 $\mathrm{pH}$ 변화를 측정하기 위하 여 $0,8,24,48$ 시간 배양 후 $\mathrm{pH}$ 변화를 측정한 결과 (Table 2), T. forsythia와 T. denticola는 배양시간에 따라서 단독배지와 혼합배지에서 모두 변화가 거의 없었으며, F. nucleatum과 P. gingivalis는 24시간 배양 후부터, A. actinomycetemcomitans는 48시간 배양 후부터 변화를 보 였다. 이 때, P. gingivalis는 24시간 배양 후부터 $\mathrm{pH}$ 가 상 승한 반면, A. actinomycetemcomitans는 배양 48시간째에 $\mathrm{pH}$ 가 유의하게 감소하였다.

\section{W. cibaria의 성장에 대한 배지의 영향}

W. cibaria가 단독 성장배지와 1:1 혼합배지에서 각각 배양하였을 때 성장의 정도에 차이가 있는지를 알아 본 결과 (Fig. 4), W. cibaria는 MRS 단독배지에서 배양하였 을 때 가장 잘 자랐으며, 24시간 배양 후 F. nucleatum과 A. actinomycetemcomitans 성장배지와 혼합한 배지보다 $\mathrm{MRS}$ 단독배지에서 배양했을 때 10배 정도 생육이 더 좋 았으나 $(p<0.05)$ 다른 균의 성장배지와 혼합한 배지에서
는 큰 차이를 보이지 않았다. 또한, 48시간 배양하였을 때 0 시간 때 보다 약 $3.84 \times 10^{3}$ 배 더 성장하고 혼합배 지에서도 $3.50 \times 10^{2} \sim 2.19 \times 10^{3}$ 배 더 성장한 변화를 볼 수 있었다. 한편, 성장에 따른 $\mathrm{pH}$ 변화를 측정한 결과, 배양 24시간부터 성장력이 가장 좋은 MRS 단독배지에서 $\mathrm{pH} 5.5$ 까지 유의하게 낮아졌으며 $(p<0.05)$, 혼합배지에 서는 큰 변화를 보이지 않았다.

\section{고 찰}

1996년 세계치주학회에서는 A. actinomycetemcomitans, P. gingivalis, T. forsythia를 파괴적 치주질환을 야기하는 치주 병원균으로 규정하였다 (23). A. actinomycetemcomitans 는 그람음성, 혐기성 세균으로 건강한 치주조직에서보다 국소적 유년형 치주염 및 사춘기전 치주염에서 증가하며 (10), P. gingivalis는 그람음성, 혐기성 세균으로 건강한 사 람이나 치은염 환자에서는 드물고 파괴성 질환에서 많이 나타나는데, 특히 치주질환이 진행된 환자에서 더 발견 되었다 $(11,24) . T$. forsythia는 그람음성, 혐기성 세균으로 

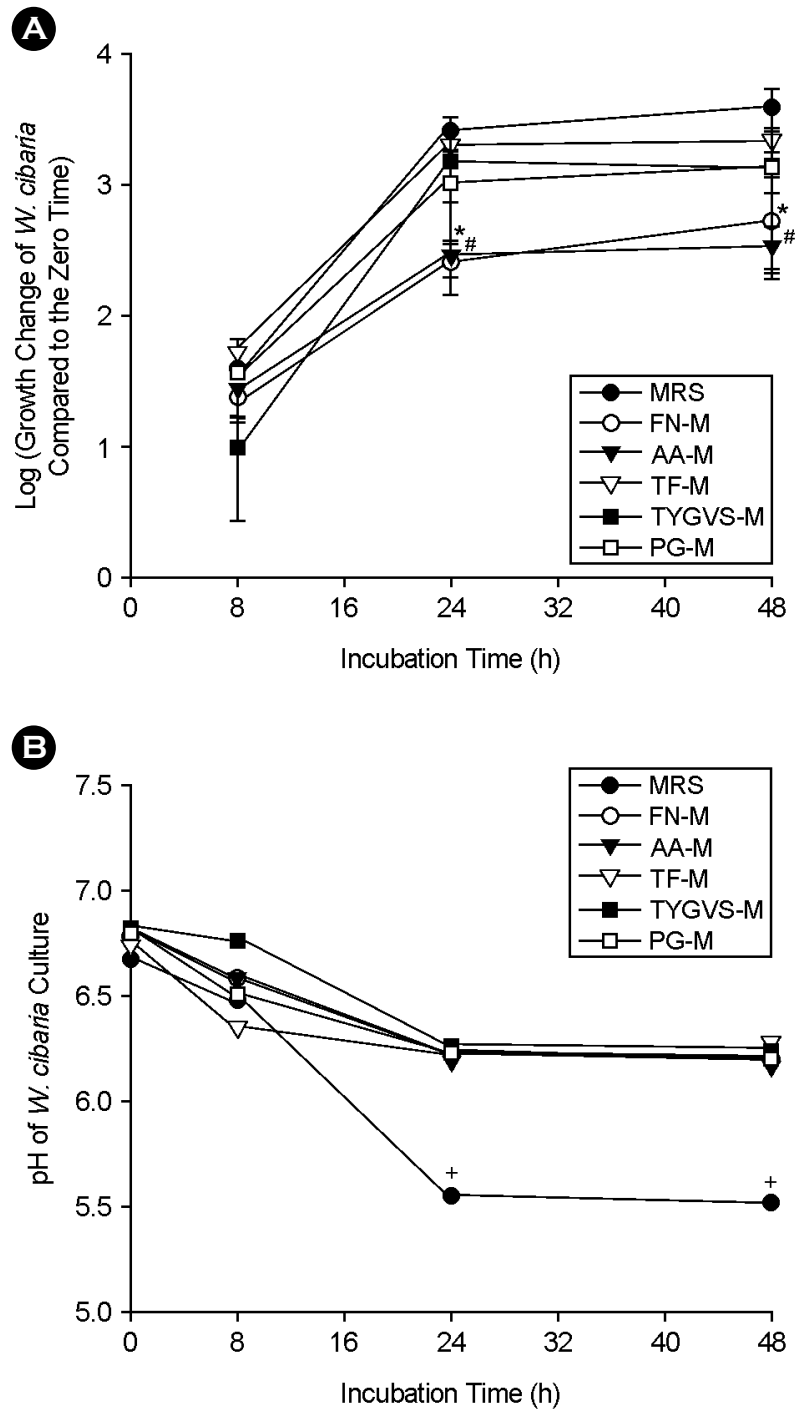

Figure 4. Comparison of bacterial cell numbers (A) and $\mathrm{pH}$ changes (B) of W. cibaria over time under different growth media conditions by real-time PCR. The growth change of $W$. cibaria compared to the zero time $(0 \mathrm{~h})$ was shown as log scale. FN-M, a mixture of equal volume of $F$. nucleatum growth medium and MRS; AA-M, a mixture of equal volume of A. actinomycetemcomitans growth medium and MRS; TF-M, a mixture of equal volume of $T$. forsythia growth medium and MRS; TYGVS-M, a mixture of equal volume of T. denticola growth medium and MRS; PG-M, a mixture of equal volume of $P$. gingivalis growth medium and MRS. ${ }^{*} p<0.05$, culture in FN-M versus culture in MRS; $\# p<$ 0.05 , culture in AA-M versus culture in MRS. $+p<0.05, \mathrm{pH}$ at over time versus $\mathrm{pH}$ at zero time.

건강한 부위나 치은염 부위보다 파괴성 치주질환 또는 치주농양 부위에 많이 보이고 비활동성 병소보다는 활동 성 병소에서 더 발견되고 (25), 건강한 치주조직에서의 병변 발생과 관련이 있는 세균으로 알려져 있다 (26). 또
한, T. denticola는 그람음성, 혐기성의 활발한 운동성을 가 진 나선균으로 건강한 사람이나 치은염 환자보다 급성 괴사성 궤양성 치주염 환자나 심한 치주염 환자에서 더 많이 나타난다 $(27,28)$. F. nucleatum은 그람음성, 혐기성, 방추형의 막대균으로 치은연하 치태에서 가장 흔히 발견 되는 세균으로 치주염과 치주농양을 가진 사람에서 널리 퍼져 있다 (29).

구강에는 치주질환을 일으키는 병원성 세균도 있지만 숙주에 유해하지 않는 세균도 상재하면서 병원균의 수를 희석하거나 병원균의 결합부와 경쟁하거나 변화시키고 병원균에 의해 생산된 독성요소를 파괴시킨다 (12). 이러 한 치주질환 원인균의 억제가 가능한 구강 상주균의 연 구가 이루어지고 있으며, 최근의 연구에서 우유나 치즈, 유산균 음료 같은 유제품을 매일 섭취하는 사람은 섭취 하지 않은 사람보다 치주낭의 깊이가 낮았으며, 부착치은 의 소실도 더 적어 매일 유산균 식품을 섭취하는 것이 치주건강에 도움이 된다고 보고하고 있다 (30). 유산균은 오랫동안 발효식품 제조에 이용되고 있을 뿐만 아니라 변비 개선 및 항암작용과 면역기능 강화 등 유익한 기능 을 나타낸다. 과거에는 장에만 국한되어 이용되었던 유산 균이 최근에는 구강건강을 위한 프로바이오틱으로서 매 력적인 약제 대체품으로 각광받고 있는데, Çaglar 등 (31, 32)은 Bifidobacterium과 Lactobacillus reuteri가 치아우식균 인 Streptococcus mutans를 감소시킨다고 보고하였으며, Hatakka 등 (33)은 Lactobacillus rhamnosus GG가 Candida albicans를 억제한다고 보고한 바 있다. 그러나, 아직까지 다양한 치주질환 원인균에 대한 유산균의 억제효과를 본 연구는 매우 드물다. 최근에 본 연구실에서는 구강에서 분리한 W. cibaria 유산균이 강산을 만들어 충치의 진행 을 돕는 Lactobacillus보다는 더 적은 양의 유산을 생성하 고, 수용성 글루캔 (soluble glucan)을 만들어 치태형성을 억제함을 보고하였고 (19), 또한 과산화수소를 생성하여 구취를 억제함과 동시에 (20), 구취 원인균 중의 하나인 F. nucleatum과 상호결합하고 상피세포에 부착능력이 있 어서 (34) 프로바이오틱으로서 구강에 적용이 가능할 것 이라고 제안하였다.

배지를 이용하여 혐기성 세균의 수를 측정하는 고전적 인 실험방법은 배지의 조성이 복잡하여 제조하기가 까다 롭고 균이 자라는데 시간이 많이 걸리며, 적은 수의 세균 을 측정하기가 매우 어렵다는 단점이 있다. 최근에 다양 한 치주 병원성 세균을 real-time PCR을 이용하여 검사해 
오고 있으며 (13 16), Boutaga 등 (35)은 배지를 이용한 고전적인 실험방법과 real-time PCR 방법을 비교한 결과 real-time PCR 실험방법이 매우 간편하면서 민감도가 더 좋았다고 보고하였다. SYBR Green을 이용한 정량 PCR 은 간편하고 값이 더 경제적이지만 정확도가 떨어진 반 면, dual-labeled probe를 이용한 방법은 보고자 하는 유전 자에 대한 특정 probe를 이용하므로 정량방법에 있어서 더 정확하고 민감도가 높은 방법이라 할 수 있다. 따라서 본 연구에서는 최신 정량 측정방법인 dual-labeled probe를 이용한 real-time PCR을 이용하여 균수를 측정함으로써 치주질환 원인균에 대한 W. cibaria 유산균의 억제효과를 정량적으로 분석하였다.

본 연구결과에서 $W$. cibaria는 배양 24시간부터 $F$. nucleatum, A. actinomycetemcomitans, T. forsythia, T. denticola 의 성장을 유의하게 억제하였으며, 특히, P. gingivalis에 대해서는 8 시간부터 성장을 현저히 억제하였다. 이전에 본 연구진들은 W. cibaria가 과산화수소를 생성하여 F. nucleatum의 성장을 억제하였다고 보고한 바 있으며 (20). 최근에는 Srionnual 등 (36)이 W. cibaria 110으로부터 그람 양성균에 대한 항균능력이 있는 박테리오신 Weissellicin 110 을 보고하였다. 따라서, 치주질환 원인균에 대한 $W$. cibaria의 항균력은 아마도 과산화수소나 박테리오신 등 을 만들어 냄으로써 발생하는 것으로 생각된다. 이로써 본 연구에서는 치주질환 원인균에 대한 W. cibaria의 항 균력을 최초로 증명하였으며, 현재 명확한 억제기전을 밝히기 위한 연구가 진행중에 있다.

이어 본 연구에서는 치주질환 원인균의 성장에 대한 W. cibaria의 억제효과를 보기 위하여 사용한 $1: 1$ 혼합배 지가 적절한 지를 보고자 하였다. W. cibaria는 치주질환 원인균 단독배지에서는 성장이 어렵고, 치주질환 원인균 은 W. cibaria의 성장배지인 MRS에 영향을 받을 것이라 생각되어 배지에 따른 세균의 성장 차이를 본 결과, red complex로 분류되는 P. gingivalis, T. forsythia, T. denticola는 모두 단독 성장배지에서 배양하였을 때 생육이 더 좋 았으나, F. nucleatum과 A. actinomycetemcomitans는 큰 차 이를 보이지 않았다. 이것은 P. gingivalis, T. forsythia, T. denticola는 MRS에 민감하게 영향을 받고, F. nucleatum과 A. actinomycetemcomitans는 큰 영향을 받지 않았기 때문 으로 생각된다. 한편, W. cibaria는 MRS 단독 배지에 비하 여 다른 $1: 1$ 혼합배지에서는 성장의 유의한 차이가 없었 으나 F. nucleatum과 A. actinomycetemcomitans 성장배지를
1:1 혼합한 배지에서는 다소 낮은 성장을 보였다. 그럼에 도 불구하고 W. cibaria는 혼합배지에서 치주질환 원인균 의 성장에 대한 억제효과를 나타내었다.

성장에 따른 $\mathrm{pH}$ 변화를 측정한 결과 $T$. forsythia와 $T$. denticola는 배양시간에 따라서 $\mathrm{pH}$ 의 변화가 거의 없었 다. 이는 이들 혐기성 균들은 성장을 하여도 $\mathrm{pH}$ 의 변화 가 거의 없기 때문으로 해석된다. 반면, F. nucleatum과 P. gingivalis는 24시간 배양 후부터 유의한 변화를 보였다. 이 중 P. gingivalis는 배지의 단백질 성분을 이용하여 성 장하면서 배지에 알칼리를 띠게 하여 $\mathrm{pH}$ 를 상승시키는 것으로 생각된다. 반면, 국소적 유년형 치주염을 일으키 는 A. actinomycetemcomitans는 다른 치주질환 원인균들과 달리 성장을 하면서 산을 만들기 때문에 48시간 배양 후 $\mathrm{pH}$ 가 감소하는 걸 볼 수 있었다. 또한, W. cibaria의 경우 성장력이 가장 좋은 $\mathrm{MRS}$ 단독배지에서 $\mathrm{pH}$ 가 가장 낮아 졌는데, 이것은 유산균의 특징인 배지의 당 성분을 이용 하여 유산을 생성하였기 때문이고, 성장의 척도인 $\mathrm{pH}$ 의 변화와 연관된다.

이상의 결과를 요약하면 W. cibaria 분리균주는 5종의 치주질환 원인균의 성장을 유의하게 억제하였으며, $W$. cibaria 및 P. gingivalis, T. forsythia, T. denticola는 배지에 따라 성장력의 변화가 있음을 real-time PCR을 이용하여 정량적으로 분석하였다. 결론적으로, W. cibaria를 치주질 환 치료에 활용하기 위한 효과기전 연구 및 동물 실험 등이 더 시행되어야 하겠으며, 향후에도 real-time PCR을 이용하여 치주질환 원인균에 대한 다른 유산균들의 억제 효과를 정량적으로 분석할 수 있을 것으로 사료된다.

\section{참 고 문 헌}

1) Papapanou PN. Epidemiology of periodontal diseases: an update. J Int Acad Periodontol 1999;1:110-6.

2) Socransky SS, Haffajee AD. The bacterial etiology of destructive periodontal disease: current concepts. J Periodontol 1992; 63:322-31.

3) Wiebe CB, Putnins EE. The periodontal disease classification system of the American Academy of Periodontology: an update. J Can Dent Assoc 2000;66:594-7.

4) Poulet PP, Duffaut D, Lodter JP. Metronidazole susceptibility testing of anaerobic bacteria associated with periodontal disease. J Clin Periodontol 1999;26:261-3.

5) Roldan S, Herrera D, Santa-Cruz I, O'Connor A, Gonzalez I, 
Sanz M. Comparative effects of different chlorhexidine mouthrinse formulations on volatile sulphur compounds and salivary bacterial counts. J Clin Periodontol 2004;31:1128-34.

6) Cho MJ, Hong SJ, Choi CH, Jeong SS. Effects of dentifrice containing extract of Galla rhois or Psoralea corylifolia on inhibition of plaque formation. J Kor Acad Dent Health 2005; 29:141-52.

7) Estafan D, Gultz J, Kaim JM, Khaghany K, Scherer W. Clinical efficacy of an herbal toothpaste. J Clin Dent 1998;9:31-3.

8) Çaglar E, Kargul B, Tanboga I. Bacteriotherapy and probiotics' role on oral health. Oral Dis 2005;11:131-7.

9) Guarner F, Perdigon G, Corthier G, Salminen S, Koletzko B, Morelli L. Should yoghurt cultures be considered probiotic? Br J Nutr 2005;93:783-6.

10) Mandell RL. A longitudinal microbiological investigation of Actinobacillus actinomycetemcomitans and Eikenella corrodens in juvenile periodontitis. Infect Immun 1984;45:778-80.

11) Haffajee AD, Socransky SS. Microbial etiological agents of destructive periodontal diseases. Periodontol 2000 1994;5:78 $-111$

12) Socransky SS, Haffajee AD, Cugini MA, Smith C, Kent RL Jr. Microbial complexes in subgingival plaque. J Clin Periodontol 1998;25:134-44.

13) Kato H, Yoshida A, Awano S, Ansai T, Takehara T. Quantitative detection of volatile sulfur compound-producing microorganisms in oral specimens using real-time PCR. Oral Dis 2005;11:67-71.

14) Sakamoto M, Takeuchi $Y$, Umeda $M$, Ishikawa $I$, Benno $Y$. Rapid detection and quantification of five periodontopathic bacteria by real-time PCR. Microbiol Immunol 2001;45:39 -44 .

15) Suzuki N, Yoshida A, Nakano Y. Quantitative analysis of multi-species oral biofilms by TaqMan Real-Time PCR. Clin Med Res 2005;3:176-85.

16) Yoshida A, Suzuki N, Nakano Y, Oho T, Kawada M, Koga T. Development of a $5^{\prime}$ fluorogenic nuclease-based real-time PCR assay for quantitative detection of Actinobacillus actinomycetemcomitans and Porphyromonas gingivalis. J Clin Microbiol 2003;41:863-6.

17) Stiles ME, Holzapfel WH. Lactic acid bacteria of foods and their current taxonomy. Int J Food Microbiol 1997;36:1-29.

18) Bjorkroth KJ, Schillinger U, Geisen R, Weiss N, Hoste B, Holzapfel WH, Korkeala HJ, Vandamme P. Taxonomic study of Weissella confusa and description of Weissella cibaria sp. nov., detected in food and clinical samples. Int J Syst Evol Microbiol 2002;52:141-8

19) Kang MS, Chung J, Kim SM, Yang KH, Oh JS. Effect of Weissella cibaria isolates on the formation of Streptococcus mutans biofilm. Caries Res 2006;40:418-25.

20) Kang MS, Kim BG, Chung J, Lee HC, Oh JS. Inhibitory effect of Weissella cibaria isolates on the production of volatile sulfur compounds. J Clin Periodontol 2006;33:226-32.

21) Kang MS, Choi EK, Choi DH, Ryu SY, Lee HH, Kang HC, Koh JT, Kim OS, Hwang YC, Yoon SJ, Kim SM, Yang KH, Kang IC. Antibacterial activity of pyrrolidine dithiocarbamate. FEMS Microbiol Lett 2008;280:250-4

22) Ohta K, Makinen KK, Loesche WJ. Purification and characterization of an enzyme produced by Treponema denticola capable of hydrolyzing synthetic trypsin substrates. Infect Immun 1986;53:213-20.

23) American Academy of Periodontology. Consensus report. Periodontal diseases: Pathogenesis and microbial factors. Ann Periodontol 1996;1:926-32.

24) Lopez NJ. Occurrence of Actinobacillus actinomycetemcomitans, Porphyromonas gingivalis and Prevotella intermedia in progressive adult periodontitis. J Periodontol 2000;71:948-54.

25) Lai CH, Listgarten MA, Shirakawa M, Slots J. Bacteroides forsythus in adult gingivitis and periodontitis. Oral Microbiol Immunol 1987;2:152-7.

26) Tanner A, Maiden MF, Macuch PJ, Murray LL, Kent RL Jr. Microbiota of health, gingivitis, and initial periodontitis. J Clin Periodontol 1998;25:85-98.

27) Listgarten MA. Electron microscopic observations of the bacterial flora of acute necrotizing ulcerative gingivitis. J Periodontol 1965;36:328-39.

28) Simonson LG, Goodman CH, Bial JJ, Morton HE. Quantitative relationship of Treponema denticola to severity of periodontal disease. Infect Immun 1988;56:726-8.

29) Dzink JL, Tanner AC, Haffajee AD, Socransky SS. Gram negative species associated with active destructive periodontal lesions. J Clin Periodontol 1985;12:648-59.

30) Shimazaki Y, Shirota T, Uchida K, Yonemoto K, Kiyohara Y, Iida M, Saito T, Yamashita Y. Intake of dairy products and periodontal disease: the Hisayama Study. J Periodontol 2008; 79:131-7

31) Çaglar E, Sandalli N, Twetman S, Kavaloglu S, Ergeneli S, Selvi S. Effect of yogurt with Bifidobacterium DN-173 010 on salivary mutans streptococci and lactobacilli in young 
adults. Acta Odontol Scand 2005;63:317-20.

32) Çglar E, Cildir SK, Ergeneli S, Sandalli N, Twetman S. Salivary mutans streptococci and lactobacilli levels after ingestion of the probiotic bacterium Lactobacillus reuteri ATCC 55730 by straws or tablets. Acta Odontol Scand 2006; 64:314-8.

33) Hatakka K, Ahola AJ, Yli-Knuuttila H, Richardson M, Poussa T, Meurman JH, Korpela R. Probiotics reduce the prevalence of oral Candida in the elderly-a randomized controlled trial. $\mathrm{J}$ Dent Res 2007;86:125-30.

34) Kang MS, Na HS, Oh JS. Coaggregation ability of Weissella cibaria isolates with Fusobacterium nucleatum and their adhesiveness to epithelial cells. FEMS Microbiol Lett 2005; 253:323-9.

35) Boutaga K, van Winkelhoff AJ, Vandenbroucke-Grauls CM, Savelkoul PH. Comparison of real-time PCR and culture for detection of Porphyromonas gingivalis in subgingival plaque samples. J Clin Microbiol 2003;41:4950-4.

36) Srionnual S, Yanagida F, Lin LH, Hsiao KN, Chen YS. Weissellicin 110, a newly discovered bacteriocin from Weissella cibaria 110, isolated from plaa-som, a fermented fish product from Thailand. Appl Environ Microbiol 2007;73:2247-50. 